\title{
German fathers and their preferences for shorter working hours for family reasons
}

\author{
Anja-Kristin Abendroth* and Stephanie Pausch* \\ Faculty of Sociology, Bielefeld University, Bielefeld, Germany
}

ABSTRACT

This study is among the first to analyze fathers' preference for shorter working hours specifying that the preference is related to the wish to spend more time with the family. Assuming that preferences are context-dependent, this article explores the relevance of the family and workplace context for preference formation. We develop need-based and capability-based arguments to contrast the job demands-resources approach and the capabilities approach in work-family research. Using a sample of 632 fathers from the German LEEP-B3 data with a representative linked employer-employee design for large work organizations we conclude that fathers' preferences for shorter working hours are indeed context-dependent and that there is more evidence for need-based arguments than opportunity based arguments. Our results indicate that fathers with young children and fathers with high work demands are more likely to desire shorter working hours, whereas a reduction in working hours appears to be unnecessary for fathers who can satisfactorily reconcile work and family life through support from their supervisors. In contrast to capability-based arguments the perception of a highly demanding work culture was not found to decrease but increase the likelihood to desire to work shorter hours.

RÉSUMÉ

Cette étude estl'une des premières à analyser les préférences des pères en termes de réduction du temps de travail comme étant liées au souhait de se consacrer davantage à leur famille. Partant du présupposé que les préférences varient en fonction du contexte, cet article examine le rôle joué par le contexte familial et professionnel dans la formation de ces préférences.

Afin de comparer le modèle exigences-ressources et l'approche des capabilités dans l'étude du rapport entre travail et famille, nous avons développé à la fois des arguments fondés sur les besoins et sur les capabilités.

Pour ceci, nous avons utilisé un échantillon de 632 pères tiré des données de l'enquête allemande LEEP-B3 réalisée sur la base d'un protocole de recherche reliant les données représentatives d'employeurs à celles d'employés au sein de grandes entreprises. L'étude montre que les préférences des pères pour une réduction de leur temps de travail dépendent effectivement du contexte et que les arguments fondés sur les besoins semblent prévaloir sur
KEYWORDS

fathers; working hours preferences; capabilities; resources and demands: family context; workplace context

\section{MOTS-CLÉS}

pères; temps de travail; préférences; contexte familial; contexte professionnel; exigences et ressources 
ceux fondés sur les opportunités. Nos résultats indiquent que les pères d'enfants en bas âge ainsi que les pères confrontés à de fortes exigences professionnelles sont plus susceptibles de souhaiter une réduction de leur temps de travail, tandis que celleci n'est pas considérée comme nécessaire par les pères capables de concilier vie professionnelle et vie familiale de manière satisfaisante grâce au soutien de leurs supérieurs. Contrairement aux arguments fondés sur les capabilités, nous avons constaté que le sentiment d'appartenir à une culture professionnelle extrêmement exigeante n'entraîne pas une baisse, mais plutôt une augmentation de la probabilité que les pères souhaitent réduire leur temps de travail.

A considerable body of research has shown that many employed parents struggle to reconcile their work and family lives owing to the incompatible demands imposed by these two domains (e.g. Bianchi \& Milkie, 2010; Schieman, Glavin, \& Milkie, 2009). Whereas mothers commonly reduce their working hours to combine the responsibilities of both these life spheres (e.g. Rosenfeld \& Birkelund, 1995; van der Lippe, 2001), fathers rarely choose to work fewer hours; in fact, they are more likely to work even longer hours - a finding common to all European countries (e.g. Fagan, 2004; Lewis, Campbell, \& Huerta, 2008). In Germany, more than half the fathers work more than 40 hours a week (IfD, 2010), thus eliciting the following questions: Do fathers prefer to work long hours and are they able to reconcile their work and family responsibilities in a satisfying way? Or do fathers struggle to combine work and family life and have fewer opportunities than mothers do to reduce their working hours?

Because the model of the male breadwinner is still the norm, the decision to work fewer hours continues to be a less acceptable option for fathers (Fagan \& Walthery, 2011; Stier \& Lewin-Epstein, 2003). Recent research has revealed a disparity between the actual and the preferred number of working hours, and, in general, more and more men wish to work fewer hours (Abendroth, Pausch, \& Böhm, 2014; Hobson \& Fahlén, 2009; Pollmann-Schult, 2008, 2009; Thornthwaite, 2004). According to Bielenski and Wagner (2004), more than half of all employed men in Europe would prefer to reduce the number of hours they work. For example, men in the United Kingdom (Maclnnes, 2005) and in the Netherlands (van Echtelt, Glebbeek, \& Lindenberg, 2006) increasingly desire such a reduction.

In our research, we focus on fathers' preference for shorter working hours, even when this decrease would affect their income, as well as on how the family and work contexts shape this preference. Based on the job demands-resources approach (Bakker \& Demerouti, 2007), we develop three need-based hypotheses, suggesting that fathers who experience high demands both in the family (e.g. having young children) and in the workplace (e.g. working overtime) are more likely to desire shorter working hours for family reasons. Going beyond individual demands and resources in the family and on the job, we further investigate the relevance of the broader work and family context. We develop two capability-based hypotheses, suggesting that preferences are formed or adapted based on available opportunities (Hobson \& Fahlén, 2009; Sen, 1992, 1999). We assume that a father's preference for shorter working hours for family reasons would depend on whether this option is available in their particular family or work context - specifically, the gendered 
division of labor, the financial situation of the family, and the workplace culture. Therefore, we pose the following research question: How do the family and workplace contexts (e.g. resources and demands in the work and family domains, financial responsibilities in the family, and workplace culture) influence fathers' preferences for shorter working hours in order to spend more time with their families?

Ourstudy contributes to previous research in threeways: First, we focus onfathers who desire shorter working hours in order to spend more time with their families; unlike previous studies, we investigate the specific reasons for this preference (Clarkberg \& Moen, 2001; Hobson \& Fahlén, 2009; Pollmann-Schult, 2008, 2009). Second, we develop needbased and capability-based arguments to contrast the job demands-resources approach (Bakker \& Demerouti, 2007; Greenhaus \& Beutell, 1985) and the capabilities approach which are common in work-family research (Hobson, 2011; Hobson \& Fahlén, 2009). Third, we make use of a linked employer-employee study (LEEP-B3) that is built around a representative sample of 100 large German work organizations and a random sample of 6454 of their employees (Diewald et al., 2014). The situation of German fathers is particularly interesting to analyze, because the traditional gender norms still prevail with respect to childcareand the respective income responsibilities of men and women (Blossfeld \& Drobnič, 2001; Drobnič \& Guillén Rodríguez, 2011). Moreover, when compared with other countries, Germany has one of the largest gender-based wage gaps, and its tax system supports the male-breadwinner model of the family (Blau \& Kahn, 2007; Budig \& England, 2001).

\section{Theory and recent research on preference formation}

The preference theory developed by Hakim $(2000,2002)$ is based on the assumption that different groups have different work-family preferences. According to this theory, women are categorized into three groups with respect to their preferences towards their involvement in work and family life: home-centered, work-centered, and adaptive. One can also assume that fathers have different preferences towards their involvement in work and family responsibilities and that not all fathers are 'work-centered'. However, this theory has often been criticized, because it argues that different groups have static preferences with regard to their involvement in employment and family tasks (Crompton \& Lyonette, 2010; Ginn et al., 1996). In line with the critics of Hakim's view, we consider work-family preferences to be context-dependent, and we therefore chose to investigate how the workplace and family contexts shape fathers' preferences for shorter working hours.

The preference for fewer working hours to devote more time to one's family reflects a specific strategy for combining work and family, as indicated by the results of work-life research (Becker \& Moen, 1999). Because the approaches currently used to reconcile work and family have not been successful, alternative strategies (such as a reduction in working hours) are needed to achieve a work-family balance. Until now, this solution was most often chosen by mothers; however, fathers today are also attempting to combine work and family life, yet they face problems in doing so (Hobson \& Fahlén, 2009; Pollmann-Schult, 2008, 2009; Thornthwaite, 2004).

The job demands-resources approach described by Bakker and Demerouti (2007) and the work-family conflict approach proposed by Greenhaus and Beutell (1985) suggest 
that demands and resources in the domains of work and of family influence an employee's risk of experiencing stress and strain that spill over from one life domain to the other, resulting in a conflict between work and family life. Both approaches imply that overly demanding family or workplace conditions probably go hand in hand with a desire for shorter working hours. When fathers are faced with excessive demands for example, caring for a young child at home or having a stressful job - they may find themselves less able to integrate the roles required in both life spheres if they are working long hours. We consider this situation to be a 'need-based' explanation of a father's preference for shorter working hours.

However, we assume that fathers' preference for shorter working hours depends not only on the struggles that accompany the reconciliation of work and family but also on whether it is an available and accepted strategy for such reconciliation with respect to the fathers' surroundings. Previous research on preference formation argues and illustrates that preferences are likely to be adapted to opportunities to realize them (Lucas, Clark, Georgellis, \& Diener, 2003; Shultz \& Lepper, 1996). The capabilities approach in work-family research has been used to specify that a person's agency in developing goals in life and in choosing how to realize these goals is influenced by that person's capabilities (Hobson \& Fahlén, 2009; Sen, 1992, 1999). According to Sen (1999), capabilities are 'substantive freedoms to choose the life one has reason to value' (p. 74). This definition suggests that there are different ways to integrate work and family in a satisfying way, but that the availability of such options is context-dependent and differs among different groups of employees. Cultural norms and values, both at home and in the workplace, set certain expectations with regard to the typical number of working hours for women and for men. More specifically, fathers' financial responsibilities due to the gendered division within the family domain, as well as the perceived organizational culture within the work domain (Kossek, Pichler, Bodner, \& Hammer, 2011; Thompson, Beauvais, \& Lyness, 1999), are likely to play a crucial role for fathers' preferences to work fewer hours as they restrict or enhance father's capabilities of a reduction in working hours (Hobson \& Fahlén, 2009). We consider these to be 'capability-based' explanations for fathers' preferences to work fewer hours so they can spend more time with their families.

\section{Family context}

Need-based arguments

The family context is likely to influence whether fathers experience the need to reduce their working hours. Because young children in particular require a considerable amount of care (Nangle, Kelley, Fals-Stewart, \& Levant, 2003; Possinger, 2013), fathers with young children would be expected to prefer shorter working hours so they can spend more time with their family. Moreover, fathers who have more than one child at home might want to support their female partners by sharing childcare and other responsibilities and would therefore want to work fewer hours. In line with this argument, previous research has shown that the presence of children in the home increases workfamily conflict (Adkins \& Premeaux, 2012; Byron, 2005; Greenhaus \& Beutell, 1985; Hill, $2005)$ and that women with young children tend to reduce their working hours (Bianchi, 2000; Hill, Märtinson, Ferris, \& Baker, 2004). Therefore, one can assume that the 
presence of a young child or more than one child at home goes along with fathers' desire to spend more time with the family. Thus, we developed our first hypothesis $(\mathrm{H} 1)$ :

Hypothesis 1: Fathers with (a) younger children or (b) more than one child are more likely to prefer shorter working hours for family reasons.

\section{Capability-based arguments}

In line with the capability-based argument, itcan be further assumed that fathers' financial responsibilities due to the gendered division of labor between work and the household will affect their opportunity to consider reducing their working hours. With regard to the division of labor in a couple household, traditional norms and values imply that the male partner bears greater responsibility for the family's financial situation and is less responsible for care-related functions (Bielby \& Bielby, 1989; Blossfeld \& Drobnič, 2001; Coltrane, 2000; Pfau-Effinger, 2009). Thus, if the female partner is not employed or the household income is relatively low fathers' capabilities to reduce working hours are likely to be lower because he is expected to be the breadwinner. In contrast, a high household income implies larger capabilities for shorter working hours because the drop in household income would be manageableand thereforea shorterworking hours an available strategy to better combine work and family life.

Based on these arguments, we developed a second, two-part hypothesis $(\mathrm{H} 2)$ :

Hypothesis 2: Fathers (a) with an unemployed female partner or (b) in families where the household income is relatively low are less likely to prefer shorter working hours for family reasons.

\section{Workplace context}

Need-based arguments

Demands. In addition to the family context, the workplace context is likely to influence whether fathers feel the need to reduce their working hours. Research on combining work and family life (e.g. Abendroth \& den Dulk, 2011; Byron, 2005) emphasizes that workplace demands, such as long working hours or overtime work, can make it difficult for fathers to reconcile both life spheres. Also, supervisory responsibilities at work often seem to reinforce the difficulty of reconciling the work and family spheres, because such responsibilities involve considerable strain and require the father to be available at all times to meet the needs of his subordinates, thus restricting his ability to spontaneously adjust work demands to family demands. This stream of research implies that high workplace demands increase the likelihood that the father will desire shorter working hours owing to problems in reconciling work and family life. In line with this, Reynolds and Aletraris (2006) found that men who worked many hours and those in professional and managerial positions were more likely to prefer shorter working hours. In keeping with our need-based argument, we developed our third hypothesis $(\mathrm{H} 3)$ :

Hypothesis 3: Fathers who (a) have long contractual working hours, (b) frequently work overtime, or (c)havesupervisory responsibilities are more likely to prefershorterworking hours for family reasons. 
Resources. The job demands-resources approach emphasizes the relevance of workplace resources that could help fathers reconcile work and family life (Bakker \& Demerouti, 2007). Such resources can mitigate or even prevent the negative consequences of work demands and might allow fathers to reach a satisfying arrangement without considering a reduction in their working hours. According to recent research, support from supervisors and colleagues, as well as supportive workplace arrangements, can help employees better combine these two life spheres (Abendroth \& den Dulk, 2011; Goh, Ilies, \& Wilson, 2015; Kossek et al., 2011). For example, supervisors could show understanding of an employee's work-family situation, or colleagues could take over work tasks in the event of unexpected childcare obligations. Supportive workplace arrangements were argued to allow more flexible adjustments between the life domains, such as flexibleworking hours, telework orjob autonomy (e.g. Behson, 2005). Therefore, the need to reduce working hours may be less urgent as support from supervisors and colleagues, as well as supportive workplace arrangements, provides alternative opportunities for fathers who are attempting to reconcile their work and family life. Thus, we developed the following additional need-based hypothesis $(\mathrm{H} 4)$ :

Hypothesis 4: Fathers who receive (a) supervisory and/or colleague support or (b) supportive workplace arrangements are less likely to prefer shorter working hours for family reasons.

\section{Capability-based arguments}

We further assume that the workplace context shapes not only the need for a reduction in working hours but also the capabilities to do so. Research on work time regimes has revealed the prevalence of the 'ideal worker norm', which is characterized by continuous full-time employment in which the employees' family responsibilities are not taken into account (Hobson \& Fahlén, 2009; Kelly, Ammons, Chermack, \& Moen, 2010). This norm implies that an employee has no responsibilities outside the workplace and should be fully dedicated to work. In line with this, previous research further indicates that employees do not make use of family-friendly programs at work when they assume that using these programs will make them appear to be less committed to their work (Thompson et al., 1999). In the same vein, the capabilities argument implies that an employee whose workplace has a strong ideal worker norm would be less likely to prefer a reduction in working hours as a way to reconcile work and family, because this preference would contradict the expectation of availability, flexibility, and family involvement. The perception that employees must be completely dedicated to work (e.g. expected to work overtime and be constantly available) and that they will be penalized if they use family-friendly workplacearrangements can createan atmosphere in which fathers mightbelievethatitis not acceptable to desire shorter working hours for family reasons. Thus, even though an organizational culture that subscribes to the ideal worker norm and that is perceived to be family-unfriendly is also known to increase work-family conflict (Allen, 2001; Thompson et al., 1999; Thompson \& Prottas, 2006), a reduction in working hours is less likely to be the available strategy to successfully combine work and family. In keeping with the capability-based argument, our fifth hypothesis (H5) is as follows:

Hypothesis 5: Fathers who perceive that they are expected (a)towork overtime, (b) to be constantly available, or (c) to be less committed when they use family supportive policies are less likely to prefer shorter working hours for family reasons. 


\section{Data and operationalization}

\section{Data}

For our analysis we used a linked employer-employee dataset based on the study 'Interactions Between Capabilities in Work and Private Life' (LEEP-B3) undertaken at the Collaborative Research Center 882 at Bielefeld University. (For more information, see Diewald et al., 2014.) This study comprised three parts: an employer survey involving 100 large work organizations (i.e. those having at least 500 employees) from various segments of the economy, an employee survey involving 6454 employees from these organizations, and an additional employee partner survey. ${ }^{1}$ Additional information on the employees' work histories and their organizations was derived from linked German administrative social security records and demographic data from the German Federal Employment Agency. The American Association for Public Opinion Research (AAPOR) response rates for the first wave (conducted in 2012/2013) were $23.6 \%$ for the employer survey and $29.8 \%$ for the employee survey. Selectivity tests comparing the sample with the German workforce employed in large work organizations indicate that the LEEP-B3 data set is representative of the workers in large work organizations, the only exceptions being employees whose nationality is not German and employees without vocational training or whose educational status is unknown, a group that is slightly underrepresented. The employer data include information about the organization's structure as well as the benefits it provides for its employees. The employee data comprise information about the employees' working conditions and their personal lives. By using the data set from this first wave, we obtained information for 1548 fathers with children who were 16 years of age or younger living in the household.

\section{Dependent variable}

We measured the employees' preference for shorter working hours as a way for them to attend to family responsibilities on the basis of their answers to three questions. The first two questions involved an established measurement that was also used by several other surveys, suchas the German Socio-EconomicPanel(SOEP) and the European Social Survey (ESS), referenced in Hobson and Fahlén (2009).

Employees were asked to state the number of hours they actually worked; their preferred number of working hours, bearing in mind that this change would affect their income; and the main reason for wanting such a reduction, if the preferred number of working hours was less than the actual amount stated. Of the total group, $55 \%$ of fathers stated that they wanted shorter working hours. Table 1 shows the distribution of the main reasons why fathers and childless men wanted to reduce their working hours. The distribution indicated that the most common stated reason was 'more leisure time' (44\%), followed by 'family reasons' $(39 \%)$. The share of childless men who desired to reduce their working hours for family reasons was rather low (5\%), whereas the great majority of the childless men wanted to reduce their working hours to have more leisure time $(74 \%)$.

Fathers whose main reason for preferring shorter working hours was related to family responsibilities (childcare, more time for the partner, more time for the family) were coded ' 1 ', and those who did not wish to reduce their working hours were coded ' 0 '. Respondents 
Table 1. Main reasons for the desire to reduce working hours.

\begin{tabular}{|c|c|c|c|c|}
\hline \multirow[b]{2}{*}{ Reason } & \multicolumn{2}{|c|}{ Fathers } & \multicolumn{2}{|c|}{ Non-fathers } \\
\hline & Freq. & Percent & Freq. & Percent \\
\hline Family reasons & 326 & 38.62 & 30 & 4.98 \\
\hline More time for the family & 209 & 24.76 & 14 & 2.32 \\
\hline More time for the partner & 40 & 4.74 & 15 & 2.49 \\
\hline Childcare & 77 & 9.12 & 0 & 0 \\
\hline Care for dependent persons & 0 & 0 & 1 & 0.17 \\
\hline More time for leisure & 373 & 44.19 & 444 & 73.63 \\
\hline Self-realization/higher quality of life & 16 & 1.89 & 6 & 0.99 \\
\hline Reducing work stress and strain & 56 & 6.64 & 63 & 10.45 \\
\hline Overtime not paid/tax reasons & 31 & 3.68 & 7 & 1.16 \\
\hline Sideline employment & 13 & 1.54 & 20 & 3.32 \\
\hline Health reasons & 12 & 1.42 & 14 & 2.32 \\
\hline Housework & 4 & 0.47 & 4 & 0.66 \\
\hline Other & 13 & 1.54 & 15 & 2.49 \\
\hline Total & 518 & 100 & 603 & 100 \\
\hline
\end{tabular}

Note: 'Family reasons' is composed of the italic items.

who reported other reasons for desiring shorter working hours were not considered in the analysis. The sample included 969 fathers whose children were age 16 years or younger and were living in the household who either preferred to reduce their working hours for family reasons or did not prefer such a reduction. As a result of missing values, the final sample used for our analysis included 632 fathers, of whom 225 desired shorter working hours and 407 did not. Of those who preferred shorter working hours, 124 preferred to reduce their contracted hours and 101 wanted to reduce their overtime. ${ }^{2}$

\section{Independent variables}

Family context. To capture fathers' need to reduce working hours, we considered the age of the youngest child (metric) and the number of children within the household ( $1=$ one child, 2 = two or more children). To consider a father's capability to reduce their working hours, we determined whether his female partner was employed ( $1=$ partner employed $)^{3}$ and used the logarithm of the amount of household net income per month (logarithmized).

Workplace context. Demands: We considered contractual working hours and the frequency of overtime to be time-related workplace demands that are known to foster conflict between work and family life (Byron, 2005). Contractual, agreed-upon working hours were measured as a continuous variable and overtime work was measured as a categorical variable $(1=$ nearly every day, $2=$ every week/several times per month, $3=$ rarely/from time to time, $4=$ never). Furthermore, we considered supervisory responsibilities to be a workplace demand $(1=$ yes $)$.

Resources: To capture support in the workplace, respondents were asked to use a 5point scale ranging from 'Applies completely (1)' to 'Does not apply at all (5)' to indicate whether supervisors supported employees in their efforts to reconcile work with family life and to determine whether coworkers helped one another to get their work done when one had to leave early or return to work late for personal reasons. We also took into account whether employees made use of flexible working hours ( $1=$ yes) or telework (1=yes). Jobautonomy (Breaugh, 1985)was measured based on three items ('During my 
working hours, I have control over the sequencing of my work activities'; 'I am allowed to decide how to go about getting my job done'; 'I am able to define what my job objectives are'), and these values were included in an index that ranged from 3 to 15 , with higher values indicating greater job autonomy.

Workplace culture: To capture whether an employee's organizational culture adhered to the ideal worker norm, we took into account the employee's perception of the work organization's expectations regarding overtime work and constant availability. Based on their position or on comparable positions within their organization, respondents were asked to rate the importance of working overtime or being constantly available by means of a 5-point scale that ranged from 'not important at all' (1) to 'very important' (5). In addition, respondents wereasked to whatextentemployees in theirorganization were perceived to be less committed if they made use of family supportive measures, according to a scale of 1-5 that ranged from 'I do not agree at all' (1) to 'I totally agree' (5). This item is labeled 'perception of commitment stigmas when using family supportive policies' in the analysis.

\section{Control variables}

We included fathers' age in our analysis, assuming that younger fathers must still invest in their careers giving them less capabilities for the preference for shorterworking hours. We also considered fathers' educational level (based on the Comparative Analysis of Social Mobility in Industrial Nations [CASMIN]), because the higher this level, the higher the opportunity costs of reducing working hours. Moreover, we included fathers' monthly income (logarithmized), because those with a high monthly net income would also have higher opportunity costs by reducing working hours if this change would affect their income.

\section{Methodology}

Given the hierarchical structure of the data, we used a multilevel approach. Having multiple workers in the same organization would violate the independence assumption inherent in conventional ordinary least squares estimators. Therefore, our analyses were based on hierarchical logistic regression that reported odds ratios in which the independent variables were incorporated stepwise. With regard to the family context, the variables in Model 1 considered need-based arguments and those in Model 2 considered capabilitybased arguments. With regard to the workplace context, the variables in Model 3 considered need-based demands and those in Model 4 considered need-based resources. Model 5 integrated indicators that illustrate the capability-based arguments in the work domain. Finally, all variables were included in the full model. ${ }^{4}$

\section{Results}

Table 2 shows the means and standard deviations or proportions of the independent variables for fathers who wished to reduce their working hours for family reasons and for those who did not. The mean ages of the youngest child indicated that the children of fathers who preferred shorter working hours were younger than the children of fathers who did not show this preference. The percentage of fathers with two or more children was larger for those who did not prefer to reduce their working hours compared with those who held this preference $(75 \%$ vs. $64 \%)$. Fathers who wanted to reduce their 
Table 2. Mean and standard deviation (SD) or proportion (\%) of independent variables according to whether or not fathers desire shorter working hours.

\begin{tabular}{|c|c|c|c|c|}
\hline \multirow{2}{*}{ Independent variables } & \multicolumn{2}{|c|}{$\begin{array}{l}\text { Desire to reduce working } \\
\text { hours for family reasons } \\
\qquad(N=225)\end{array}$} & \multicolumn{2}{|c|}{$\begin{array}{l}\text { No desire to reduce } \\
\text { working hours ( } N \\
=407)\end{array}$} \\
\hline & Mean or \% & SD & Mean or \% & SD \\
\hline \multicolumn{5}{|l|}{ Family context: Need } \\
\hline Age of youngest child (yr) & $6.818^{* * *}$ & $(4.600)$ & 8.437 & $(4.648)$ \\
\hline \multicolumn{5}{|l|}{ Number of children } \\
\hline One child & $36.44 \%$ ** & & $24.82 \%$ & \\
\hline Two or more children & $63.56 \%$ ** & & $75.18 \%$ & \\
\hline \multicolumn{5}{|l|}{ Family context: Capability } \\
\hline Ln (monthly household net income) & 8.242 & $(0.371)$ & 8.211 & $(0.422)$ \\
\hline Partner employed & $76.00 \%$ & & $75.43 \%$ & \\
\hline \multicolumn{5}{|l|}{ Workplace context: Need-demands } \\
\hline Contractual working hours & $38.816^{\star \star \star}$ & $(2.753)$ & 37.714 & $(4.142)$ \\
\hline Supervisory responsibilities & $58.67 \%$ ** & & $47.67 \%$ & \\
\hline \multicolumn{5}{|l|}{ Frequency of working overtime } \\
\hline Nearly every day & $36.89 \%$ * & & $27.76 \%$ & \\
\hline Every week/several times per month & $38.22 \%$ * & & $30.47 \%$ & \\
\hline Rarely/from time to time & $21.78 \%$ * & & $30.96 \%$ & \\
\hline Never & $3.1 \%$ *** & & $10.81 \%$ & \\
\hline \multicolumn{5}{|l|}{ Workplace context: Need-resources } \\
\hline Support from supervisors & $3.893^{*}$ & $(1.008)$ & 4.079 & $(1.036)$ \\
\hline Support from colleagues & 4.058 & $(1.057)$ & 4.170 & (1.052) \\
\hline Flexible working hours & $60.44 \%$ & & $63.64 \%$ & \\
\hline Telework & $27.11 \%$ ** & & $17.94 \%$ & \\
\hline Job autonomy & 11.147 & $(2.574)$ & 10.936 & $(2.903)$ \\
\hline \multicolumn{5}{|l|}{ Workplace context: Capability } \\
\hline $\begin{array}{l}\text { Perception of commitment stigmas when } \\
\text { using family supportive policies }\end{array}$ & $2.249^{*}$ & $(1.138)$ & 2.039 & $(1.133)$ \\
\hline Perception that working overtime is expected & $4.093^{\star \star *}$ & $(0.816)$ & 3.791 & $(1.043)$ \\
\hline Perception that being constantly available is expected & $3.093^{* * *}$ & $(1.216)$ & 2.705 & (1.148) \\
\hline \multicolumn{5}{|l|}{ Control variables } \\
\hline Age & 41.99 & $(6.518)$ & 43.03 & $(6.414)$ \\
\hline Low education level & $12.00 \%$ & & $14.74 \%$ & \\
\hline Medium education level & $40.44 \%$ * & & $48.65 \%$ & \\
\hline High education level & $47.56 \%$ ** & & $36.61 \%$ & \\
\hline Ln (monthly income) & 8.402 & $(0.489)$ & 8.345 & $(0.485)$ \\
\hline
\end{tabular}

working hours worked longer hours than did fathers without this preference; the average number of actual working hours perweek was more than 4 hours longer, and they worked overtime more frequently. Table 3 shows the correlations of all the independent variables and indicates no problem of multicollinearity.

Table 4 shows the results of the multilevel regression analysis. Model 1 includes needbased arguments regarding the family context, such as the number of children in the household and the age of the youngest child. The results indicated that with each additional year of age of the youngest child, the odds of wanting shorter working hours decreased by a factor of 0.914 , which is in line with hypothesis $\mathrm{H} 1 \mathrm{a}$. However, hypothesis $\mathrm{H} 1 \mathrm{~b}$ was not supported. Surprisingly, fathers who had one child were more likely to desire a reduction in working hours than were fathers who had two or more children. This result was already evident in the descriptive. The control variables showed no significant effects.

Model 2 provided noevidence for the capability-based hypothesis in the family context ( $\mathrm{H} 2 \mathrm{a}$ and $\mathrm{H} 2 \mathrm{~b})$. Neither the employment situation of the female partner nor the household income had a significant effect on the fathers' preference for reducing working hours. 
Table 3. Intercorrelations of independent variables.

\begin{tabular}{|c|c|c|c|c|c|c|c|c|c|c|c|c|}
\hline & Independent variables & 1 & 2 & 3 & 4 & 5 & 6 & 7 & 8 & 9 & 10 & 11 \\
\hline & Age of youngest child (yr) & - & & & & & & & & & & \\
\hline & Two or more children & $0.1395^{*}$ & - & & & & & & & & & \\
\hline & Ln (monthly household net income) & $0.0365^{*}$ & $0.0905^{*}$ & - & & & & & & & & \\
\hline & Partner employed & $0.1218^{\pi}$ & $-0.061 /^{\pi}$ & $0.181 /^{*}$ & - & & & & & & & \\
\hline & Contractual workıng nours & $-0.06 y 7^{\circ}$ & -0.0013 & U.0827" & $-0.042 U^{n}$ & - & & & & & & \\
\hline & Supervisory responsibilities & $0.0766^{*}$ & $0.0446^{*}$ & $0.1986^{*}$ & 0.0106 & $0.1350^{*}$ & - & & & & & \\
\hline & Overtime: Nearly every day & 0.0068 & -0.0245 & $0.1791^{*}$ & $-0.0896^{*}$ & $0.0673^{*}$ & $0.1567^{\star}$ & - & & & & \\
\hline & Overtime: Every week/several times per month & $-0.0851^{*}$ & $-0.0311^{*}$ & -0.0070 & $0.0561^{*}$ & $0.0504^{*}$ & $-0.0358^{*}$ & $-0.4730^{*}$ & - & & & \\
\hline & Overtime: Rarely/from time totime & $0.0508^{*}$ & $0.0364^{*}$ & $-0.1664^{*}$ & 0.0053 & $-0.0509^{*}$ & $-0.0939^{*}$ & $-0.4149^{*}$ & $-0.4365^{\star}$ & - & & \\
\hline & Support from supervisors & $-0.0295^{\star}$ & $-0.0329^{*}$ & $0.0440^{*}$ & -0.0074 & $-0.1148^{*}$ & 0.0027 & $-0.0515^{*}$ & 0.0175 & $0.0405^{\star}$ & - & \\
\hline & Support from colleagues & 0.0005 & $-0.0770^{*}$ & $-0.1185^{\star}$ & 0.0174 & $-0.0952^{*}$ & 0.0141 & $-0.0858^{*}$ & -0.0167 & $0.1050^{*}$ & $0.3097^{*}$ & - \\
\hline & Flexible working hours & $0.1060^{*}$ & $0.0387^{\star}$ & $0.0533^{*}$ & $0.0476^{*}$ & $-0.0984^{*}$ & $-0.0441^{*}$ & 0.0177 & $0.0677^{\star}$ & $-0.0612^{*}$ & $0.1908^{*}$ & -0.0008 \\
\hline & 3 Telework & $-0.0275^{\star}$ & $0.0324^{*}$ & $0.2468^{\star}$ & $0.0961^{*}$ & $0.0291^{*}$ & 0.0223 & 0.0121 & $0.1025^{*}$ & $-0.0701^{*}$ & $0.1292^{*}$ & $-0.0418^{*}$ \\
\hline & Job autonomy & 0.0237 & -0.0075 & $0.1660^{*}$ & $-0.0334^{*}$ & $-0.0387^{*}$ & $0.1878^{*}$ & $0.1004^{*}$ & 0.0092 & $-0.0786^{*}$ & $0.2037^{\star}$ & $0.0631^{*}$ \\
\hline & $\begin{array}{l}\text { Perception of commitmentstigmas when using } \\
\text { ramıly supporuve policies }\end{array}$ & $-0.0697^{*}$ & -0.0189 & -0.0250 & $0.1022^{\star}$ & -0.0037 & -0.0199 & $0.0441^{*}$ & 0.012 & $-0.0526^{*}$ & $-0.2285^{*}$ & $-0.1417^{*}$ \\
\hline 16 & Perception that working overtime is expected & $-0.0701^{*}$ & -0.0090 & $0.0457^{*}$ & $-0.0362^{*}$ & $0.0334^{*}$ & -0.0064 & $0.1115^{*}$ & $0.0319^{*}$ & $-0.0698^{*}$ & $-0.0507^{\star}$ & 0.0143 \\
\hline 17 & $\begin{array}{l}\text { Perception that being constantly available is } \\
\text { expected }\end{array}$ & -0.0028 & 0.0128 & $0.1065^{*}$ & $0.0307^{\star}$ & $0.0834^{*}$ & $0.1044^{*}$ & $0.0569^{*}$ & $0.0422^{\star}$ & $-0.0734^{*}$ & $-0.1270^{*}$ & $-0.0471^{*}$ \\
\hline 18 & 3 Age & $0.6344^{\circ}$ & $0 . \angle 4<3^{n}$ & $0.15 / 0^{\circ}$ & U.UbZUn & $-U .1051^{\circ}$ & U.U/3U" & U.04/U & $-0.10 / y^{n}$ & $0.050 r^{\circ}$ & $-0.0810^{n}$ & $-0.1050^{\circ}$ \\
\hline & Medium education level & -0.0154 & -0.0022 & $-0.2203^{*}$ & -0.0265 & -0.0030 & $-0.1085^{\star}$ & $-0.1279^{\star}$ & $0.0875^{\star}$ & $0.0282^{*}$ & -0.0020 & 0.0196 \\
\hline & High education level & $-0.0552^{*}$ & 0.0009 & $0.3921^{*}$ & $0.0479^{*}$ & $0.0547^{*}$ & $0.1351^{*}$ & $0.2272^{*}$ & $-0.0415^{\star}$ & $-0.1504^{*}$ & $0.0620^{*}$ & $-0.0649^{*}$ \\
\hline & Ln (monthly income) & $\begin{array}{l}0.1429^{*} \\
12\end{array}$ & $\begin{array}{l}0.1019^{*} \\
13\end{array}$ & $\begin{array}{l}0.6229^{*} \\
14\end{array}$ & $\begin{array}{l}0.0539^{*} \\
15\end{array}$ & $\begin{array}{l}0.2365^{*} \\
16\end{array}$ & $\begin{array}{l}0.2830^{*} \\
17\end{array}$ & $\begin{array}{l}0.3108^{\star} \\
18\end{array}$ & $\begin{array}{l}-0.1049^{*} \\
19\end{array}$ & $\begin{array}{l}-0.1868^{*} \\
20\end{array}$ & 0.0227 & $-0.0792^{*}$ \\
\hline 13 & Telework & $0.2259^{*}$ & - & & & & & & & & & \\
\hline 142 & Job auton & $0.3149^{*}$ & $51^{*}$ & & & & & & & & & \\
\hline & $\begin{array}{l}\text { Perception of commitment stigmas when using } \\
\text { family supportive policies }\end{array}$ & $-0.0862^{*}$ & -0.0247 & $-0.1107^{*}$ & - & & & & & & & \\
\hline & Perception that working overtime is expected & $-0.0502^{*}$ & -0.0136 & $0.0445^{\star}$ & $0.1143^{*}$ & - & & & & & & \\
\hline & $\begin{array}{l}\text { Perception that being constantly available is } \\
\text { expected }\end{array}$ & ? & $0.1502^{*}$ & $0.0762^{*}$ & $0.1459^{*}$ & $0.3033^{*}$ & - & & & & & \\
\hline 8 & Age & $0.1332^{*}$ & $0.0423^{*}$ & $0.0510^{*}$ & 0.0046 & -0.0233 & $0.0679^{*}$ & - & & & & \\
\hline & $\begin{array}{l}\text { Medium education level } \\
\text { High education level }\end{array}$ & $\begin{array}{c}-0.1353^{*} \\
0.2397^{*}\end{array}$ & $\begin{array}{r}-0.1420^{*} \\
0.2738^{*}\end{array}$ & $\begin{array}{r}-0.1073^{*} \\
0.2302^{*}\end{array}$ & $\begin{array}{c}-0.0361^{*} \\
0.0024\end{array}$ & $\begin{array}{r}0.0171 \\
-0.0365^{*}\end{array}$ & $\begin{array}{l}0.0222 \\
0.0193\end{array}$ & $\begin{array}{r}-0.1100^{*} \\
0.0754^{*}\end{array}$ & $-\overline{0.7574^{*}}$ & - & & \\
\hline 21 & Ln (monthly income) & $0.1668^{*}$ & $0.2808^{*}$ & $0.2184^{*}$ & $-0.0384^{*}$ & $0.0338^{*}$ & $0.1162^{*}$ & $0.2458^{*}$ & $-0.2426^{*}$ & $0.4286^{*}$ & & \\
\hline
\end{tabular}

$0.1668^{*} \quad 0.2808^{*} \quad 0.2184^{*}-0.0384^{*}$

$0.0338^{*} \quad 0.1162^{*} \quad 0.2458^{*}-0.2426^{*} \quad 0.4286^{*}$ 


\begin{tabular}{|c|c|c|c|c|c|c|c|c|c|c|c|c|}
\hline & \multicolumn{2}{|c|}{$\begin{array}{c}\text { Model } 1 \\
\text { Family context: } \\
\text { Need }\end{array}$} & \multicolumn{2}{|c|}{$\begin{array}{c}\text { Model } 2 \\
\text { Family context: } \\
\text { Capability }\end{array}$} & \multicolumn{2}{|c|}{$\begin{array}{c}\text { Model } 3 \\
\text { Workplace } \\
\text { context: } \\
\text { Need-demands }\end{array}$} & \multicolumn{2}{|c|}{$\begin{array}{l}\text { Model } 4 \\
\text { Workplace } \\
\text { context: } \\
\text { Need- } \\
\text { resources }\end{array}$} & \multicolumn{2}{|c|}{$\begin{array}{l}\text { Model } 5 \\
\text { Workplace } \\
\text { context: } \\
\text { Capability }\end{array}$} & \multicolumn{2}{|c|}{ Full model } \\
\hline & OR & SE & OR & SE & OR & SE & OR & SE & OR & SE & OR & SE \\
\hline \multicolumn{13}{|l|}{ Family context: Need } \\
\hline Age of youngest child (yr) & $0.914^{* \star *}$ & $(0.023)$ & & & & & & & & & $0.917^{* *}$ & $(0.025$ \\
\hline Two and more children & $0.584^{* *}$ & $(0.118)$ & & & & & & & & & $0.574^{* *}$ & $(0.120$ \\
\hline \multicolumn{13}{|l|}{ Family context: Capability } \\
\hline Ln (monthly household net income) & & & 0.934 & $(0.278)$ & & & & & & & 0.808 & $(0.261$ \\
\hline Partner employed & & & 1.027 & $(0.216)$ & & & & & & & 1.134 & $(0.258$ \\
\hline \multicolumn{13}{|l|}{ Workplace context: Need-demands } \\
\hline Contractual working hours & & & & & $1.081^{*}$ & $(0.035)$ & & & & & $1.079^{*}$ & $(0.038$ \\
\hline $\begin{array}{l}\text { Supervisory responsibilities } \\
\text { Frequency of working overtime (ref=never) }\end{array}$ & & & & & $1.445+$ & $(0.277)$ & & & & & $1.541^{*}$ & $(0.315$ \\
\hline Nearly every day & & & & & $4.038^{* *}$ & $(1.859)$ & & & & & $3.255^{\star}$ & $(1.555$ \\
\hline Every week/several times per month & & & & & $3.970^{* *}$ & (1.804) & & & & & $3.244^{*}$ & $(1.525$ \\
\hline Rarely/from time to time & & & & & $2.462+$ & (1.138) & & & & & $2.268+$ & $(1.081$ \\
\hline \multicolumn{13}{|l|}{ Workplace context: Need—resources } \\
\hline Support from supervisors & & & & & & & $0.793^{*}$ & $(0.076)$ & & & 0.852 & $(0.087$ \\
\hline Support from colleagues & & & & & & & 0.968 & $(0.087)$ & & & 0.976 & $(0.092$ \\
\hline Flexible working hours & & & & & & & 0.793 & $(0.166)$ & & & 0.899 & $(0.201$ \\
\hline Telework & & & & & & & $1.757^{*}$ & $(0.436)$ & & & $1.598+$ & $(0.419$ \\
\hline Job autonomy & & & & & & & 1.034 & $(0.037)$ & & & 1.012 & $(0.039$ \\
\hline \multicolumn{13}{|l|}{ Workplace context: Capability } \\
\hline Perception of commitment stigmas when using family supportive policies & & & & & & & & & 1.111 & $(0.090)$ & 1.059 & $(0.091$ \\
\hline Perception that working overtime is expected & & & & & & & & & $1.305^{\star *}$ & $(0.134)$ & $1.264^{*}$ & $(0.137$ \\
\hline Perception that being constantly available is expected & & & & & & & & & $1.272^{* *}$ & $(0.104)$ & $1.192^{*}$ & $(0.103$ \\
\hline \multicolumn{13}{|l|}{ Control variables } \\
\hline $\begin{array}{l}\text { Age } \\
\text { Education level }(\text { ref }=\text { low) }\end{array}$ & 1.021 & $(0.019)$ & $0.973+$ & $(0.014)$ & 0.981 & $(0.015)$ & $0.971^{*}$ & $(0.014)$ & $0.971^{*}$ & $(0.014)$ & 1.025 & $(0.021$ \\
\hline Medium education level & 0.901 & $(0.263)$ & 0.939 & $(0.269)$ & 0.839 & $(0.246)$ & 0.936 & $(0.271)$ & 0.955 & $(0.280)$ & 0.826 & $(0.252$ \\
\hline High education level & 1.258 & $(0.405)$ & 1.439 & $(0.457)$ & 1.234 & $(0.397)$ & 1.379 & $(0.450)$ & 1.551 & $(0.501)$ & 1.178 & $(0.408$ \\
\hline Ln (monthly income) & 1.373 & $(0.310)$ & 1.318 & $(0.346)$ & 0.891 & $(0.213)$ & 1.140 & $(0.257)$ & 1.151 & $(0.259)$ & 0.890 & $(0.261$ \\
\hline Constant & $0.041+$ & $(0.076)$ & 0.256 & $(0.555)$ & 0.042 & $(0.088)$ & 1.117 & $(2.082)$ & 0.067 & $(0.123)$ & 0.043 & $(0.120$ \\
\hline
\end{tabular}

Note: $+\mathrm{p}<0.1 ;{ }^{*} \mathrm{p}<0.05 ;{ }^{* *} \mathrm{p}<0.01 ;{ }^{* * *} \mathrm{p}<0.001$ (two-tailed test). OR= odds ratio; SE = standard error. 
The results concerning workplace demands in Model 3 support hypothesis $\mathrm{H} 3$, which states that fathers whose work is highly demanding are more likely to desire a reduction in their working hours to allow them more time with their families. The contractual working hours, supervisory responsibilities, and frequent overtime showed a significant positive effect. For example, fathers who worked overtime nearly every day were more than four times more likely to desire shorter working hours than were fathers who never worked overtime.

With regard to resources in the workplace, the results for Model 4 showed that fathers who received work-family support from supervisors were less likely to desire shorter working hours, which is in line with hypothesis $\mathrm{H} 4$. However, telework, which organizations often advertise as a family-friendly program, had the opposite effect, in that fathers who teleworked were more likely to want to reduce their working hours than were fathers who did not telework. Moreover, flexible working times and support from colleagues were not significant.

Model 5 included indicators of the perceived workplace culture. The perception within the organization that overtime work is expected (odds ratio $=1.305$ ) or that the employee should be constantlyavailable (odds ratio $=1.272$ ) increases the likelihood thatfathers will wish to reduce their working hours. The perception that employees who made use of family supportive measures were less committed to their organization showed no significant effect. This finding is contrary to capability hypothesis $\mathrm{H} 5$, which suggested that fathers who perceive a strong ideal worker norm as part of their workplace culture were less likely to prefer a reduction in their working hours for family reasons.

In the full model, most results remained unchanged, with the exceptions that the effect of supervisor support disappeared. The reason for this was the inclusion of the organizational culture variables (the perception that constant availability and overtime work are expected, as well as a family-unfriendly workplace culture).

\section{Discussion}

This study is among the first to analyze fathers' desire to work shorter hours specifying that the desire is related to the wish to spend more time with the family. Previous research was not designed to distinguish whether fathers' desire to work fewer hours was related to family reasons or to other factors. In line with earlier studies that focused on fathers' working hour preferences in Europe (Bielenski \& Wagner, 2004), we found that more than half the sample of fathers employed in large German work organizations (55\%) would like to work fewer hours; however, there are several reasons for this preference. The two major reasons we found in our study were that fathers desired more time for leisure activities or more time to attend to the family. Men without children rarely cited the latter reason. Moreover, additional sensitivity tests highlight the importance to differentiate working hour preferences for the reasons why shorter working hours are desired while studying the implications of the family and work context.

Based on the critiques of Hakim's preference theory (Crompton \& Lyonette, 2010; Ginn et al., 1996; Hakim, 2000, 2002), we assumed that fathers' working hour preferences are not static but are instead context-dependent. Advancing previous research, we developed and tested both need-based arguments (following the demands-resources approach in worklife research, e.g. Bakker \& Demerouti, 2007), and capability-based arguments (following 
the capabilities approach in work-life research e.g. Hobson \& Fahlén, 2009) with respect to

fathers' preference for shorter working hours. The need-based arguments refer to demands and resources in the work and family domains that either restrict or enhance reconciliation of these two life domains, and these demands and resources therefore prompt a new strategy to achieve this goal, such as shorter working hours to allow more time for one's family. The capability-based arguments refer to the broader work and family contexts (such as financial responsibilities that result from the gendered division of labor) and the workplace culture, which influence whether a reduction in working hours is perceived as an available alternative for reconciling work and family life.

We conclude that fathers' preferences for shorter working hours are indeed contextdependent and that there is more evidence to support the need-based arguments than the capability-based arguments. In line with the need-based arguments, our findings show that factors within the family domain (e.g. the age of the youngest child) as well as those in the work domain (long working hours, frequency of overtime, supervisory responsibilities) increase the likelihood that a father will desire shorter working hours. The fact that number of children had the opposite effect - that is, fathers with two or

more children had a lower preference for reducing their working hours for family reasons - indicates that fathers desire to change their working hours primarily for their first newborn, but that they are less desirous of such a reduction as they begin to have more children. Possibly fathers who have already adjusted their work-family situation to accommodate a firstborn do not feel the need for such adjustments as their family grows, or perhaps they become less engaged in family matters and become more concerned with the financial position of the household.

Concerning need-based arguments, our research also revealed the importance of resources in the work domain, namely that work-life supportfrom supervisors decreased the likelihood that fathers would prefer shorter working hours. The fact that this effect disappeared when the culture of the workplace was taken into account indicates that employees who report receiving supervisory support do not perceive their workplace as conforming to a strong ideal worker norm. Rather, it would seem that supervisory support is more likely to exist in workplaces with a weak ideal worker norm. This finding is in line with recent research showing that supervisors' attitudes towards work schedules are important when it comes to their employees' ability to successfully combine work and family life (e.g. Goh et al., 2015; Kossek et al., 2011). Support from colleagues did not show a similar effect, although previous research has shown that such support does reduce problems related to the integration of work and family (e.g. Döge, Behnke, Kassner, \& Reuyss, 2005); thus, this kind of support is not a valid alternative to the strategy of reducing fathers' working hours as a way to reconcile their work and family lives.

In contrast, we found that supportive workplace arrangements did not decrease the likelihood that fathers would prefer shorter working hours. Rather, engaging in teleworking actually fostered fathers' desire to reduce their working hours. This finding is in line with previous research indicating that engaging in a flexible work arrangement (which has been labeled as a supportive workplace arrangement)can havedifferent implications depending on its implementation - that is, rather than being a resource to improve the integration of work and family life, such flexibility blurs the boundaries between life domains (Desrochers \& Sargent, 2004; Glavin \& Schieman, 2012). 
Furthermore, our findings did not support the capability-based arguments. There was no evidence that a more traditional division of labor within couples, a relatively low household income, or a workplace culture that followed the ideal worker norm decreased the likelihood that fathers would prefer shorter working hours. Instead, even the perception of a highly demanding work culture, as based on the ideal worker norm (i.e. when working overtime and being constantly available are expected), was found to increase the likelihood that fathers would desire shorter working hours. It seems that the demands of the workplace, which go hand in hand with a strong ideal worker norm culture, are so severe and influential for the experience of work-family conflicts that they outweigh the pressure to be an ideal worker.

Nevertheless, our results concerning the capability-based arguments do notimply that fathers' work-life strategies are not shaped by their capabilities. Perhaps family and workplace characteristics that impair a father's ability to shorten his working hours have a greater influence on whether such a reduction is actually realized than does the desire itself. Concerning the preference for shorter working hours, the difficulties one faces in attempting to integrate work and family life are sogreatthat the more general societal and organizational expectations with respect to fathers' working hours do not seem to play a role. Moreover, the growing discourse concerning new fathers who participate more in family life, which is prevalent in Germany (Döge et al., 2005; Possinger, 2013), may have already fostered the perception that shorter working hours are an available option.

Our findings provide support for recent political debates concerning fathers' greater involvement in family responsibilities. Proposals such as limiting the amount of working hours to 32 hours per week for all parents are one way of enabling fathers to spend more time with their families.

In the future, it would be worthwhile to examine longitudinal data concerning the desire of fathers for shorter working hours. Our study, which relied on cross-sectional data, could not disentangle the causal relationship between fathers' preference for shorter working hours and their family and work situations. Longitudinal data would permit an analysis of the relevance of the family and workplace contexts to fathers' ability to realize their working hour preferences. Moreover, collecting data in other countries on fathers' preferences for reducing working hours specifically for family reasons would make it possible to investigate whether the relevance of the workplace and family contexts varies across countries.

\section{Notes}

1. Workers subject to the social security insurance contribution were selected. In Germany, almost every worker is covered by social insurance paid for jointly by the employer and worker. Only those employees who work very few hours or who have a limited amount of earnings (currently below 450 euros per month) are not covered by social insurance.

2. We performed additional sensitivity tests applying different specifications to the dependent variable. We re-estimated our models two times: once by defining the preference to work shorter hours with a mismatch of actual and preferred work hours by at least 4 hours, and once by calculating the differences between preferred and actual hours. The results of these sensitivity tests looked very much like our reported results, and in some cases the effects were even larger. Only the effect of number of children was no longer significant, which suggests that this finding was less robust. 
3. In an additional analysis, we used information on the female partner's gross income to determine how much income the female partner contributed to the household. The effect of this variable was not significant, and owing to the relatively high amount of missing data, we decided not to include this variable in our analysis.

4. In additional analyses, we investigated how the workplace and family contexts shaped the preference to work shorter hours for leisure time reasons and for stress/strain/health reasons in different ways, and we compared the results with our analysis. Wealso performed an analysis in which we considered all employees who desired to work shorter hours. The results showed similarities and differences, indicating the need to analyze the specified preference to reduce working hours according to the reason for the preferred reduction.

\section{Disclosure statement}

No potential conflict of interest was reported by the authors.

\section{Funding}

This research was supported by the German Research Foundation (DFG) [grant number SFB 882/1 2011].

\section{References}

Abendroth, A.-K., \& den Dulk, L. (2011). Support for the work-life balance in Europe: The impact of state, workplace and family support on work-life balance satisfaction. Work, Employment \& Society, 25, 234-256.

Abendroth, A.-K., Pausch, S., \& Böhm, S. (2014). Germanfathersand theirpreferenceto reduce working hours to care for their children (SFB 882 Working Paper No. 41). Bielefeld: DFG Research Center (SFB) 882 'From Heterogeneities to Inequalities'.

Adkins, C. L., \& Premeaux, S. F. (2012). Spending time: The impact of hours worked on work-family conflict. Journal of Vocational Behavior, 80, 380-389.

Allen, T. D. (2001). Family-supportive work environments: The role of organizational perceptions. Journal of Vocational Behavior, 58, 414-435. 
Bakker, A. B., \& Demerouti, E. (2007). The job demands-resources model: State of the art. Journal of Managerial Psychology, 22, 309-328.

Becker, P. E., \& Moen, P. (1999). Scaling back: Dual-earner couples' work-family strategies. Journal of Marriage and the Family, 61, 995-1007.

Behson, S. J. (2005). The relative contribution of formal and informal organizational work-family support. Journal of Vocational Behavior, 66, 487-500.

Bianchi, S. M. (2000). Maternal employment and time with children: Dramatic change or surprising continuity? Demography, 37, 401-414.

Bianchi, S. M., \& Milkie, M. A. (2010). Work and family research in the first decade of the 21 stcentury. Journal of Marriage and Family, 72, 705-725.

Bielby, W. T., \& Bielby, D. D. (1989). Family ties: Balancing commitments to work and family in dual earner households. American Sociological Review, 54,776-789.

Bielenski, H., \&Wagner, A. (2004). Employmentoptions of menand women in Europe. In J.Z. Giele \& E. Holst (Eds.), Changing life patterns in Western industrial societies (Vol. 8, pp. 137-162). Oxford: Elsevier.

Blau, F. D., \& Kahn, L. M. (2007). Changes in the labor supply behavior of married women: 1980-2000. Journal of Labor Economics, 25, 393-438.

Blossfeld, H.-P., \& Drobnič, S. (2001). Careers of couples in contemporary society: From male breadwinner to dual-earner families. Oxford: Oxford University Press.

Breaugh, J. A. (1985). The measurement of work autonomy. Human Relations, 38, 551-570.

Budig, M.J., \&England, P.(2001). Thewage penalty formotherhood. American Sociological Review, 66, 204-225.

Byron, K. (2005). A meta-analytic review of work-family conflict and its antecedents. Journal of Vocational Behavior, 67, 169-198.

Clarkberg, M., \& Moen, P. (2001). Understanding the time-squeeze: Married couples' preferred and actual work-hour strategies. American Behavioral Scientist, 44, 1115-1136.

Coltrane, S. (2000). Research on household labor: Modeling and measuring the social embeddedness of routine family work. Journal of Marriage and Family, 62, 1208-1233.

Crompton, R., \& Lyonette, C. (2010). Family, class and gender 'strategies' in mothers' employment and childcare. In J. Scott, R. Crompton, \& C. Lyonette (Eds.), Genderinequalities in the 21st century: New barriers and continuing constraints (pp. 174-192). Cheltenham: Edward Elgar.

Desrochers, S., \& Sargent, L. D. (2004). Boundary/border theory and work-family integration. Organization Management Journal, 1, 40-48.

Diewald, M., Schunck, R., Abendroth, A.-K., Melzer, S. M., Pausch, S., Reimann, M., ... Jacobebbinghaus, P. (2014). The SFB-B3 Linked Employer-Employee Panel Survey (LEEP-B3). Schmollers Jahrbuch, 134, 379-389.

Döge, P., Behnke, C., Kassner, K., \& Reuyss, S. (2005). Auch Männer haben ein Vereinbarkeitsproblem: Ansätze zur Unterstützung familienorientierter Männer auf betrieblicher Ebene: Pilotstudie (IAIZSchriftenreihe No. 3). Berlin: Institut für anwendungsorientierte Innovations- und Zukunftsforschung.

Drobnič, S., \& Guillén Rodríguez, A. M. (2011). Tensions between work and home: Job quality and working conditions in the institutional contexts of Germany and Spain. Social Politics: International Studies in Gender, State \& Society, 18, 232-268.

van Echtelt, P. E., Glebbeek, A. C., \& Lindenberg, S. M. (2006). The new lumpiness of work: Explaining the mismatch between actual and preferred working hours. Work, Employment \& Society, 20, 493-512.

Fagan, C. (2004). Gender and working time in industrialized countries. In J. C. Messenger (Ed.), Working time and workers' preferences in industrialized countries: Finding the balance (pp. 108146). Abingdon: Routledge.

Fagan, C., \& Walthery, P. (2011). Individual working-time adjustments between full-time and parttime working in European firms. Social Politics: International Studies in Gender, State \& Society, 18, 269-299.

Ginn, J., Arber, S., Brannen, J., Dale, A., Dex, S., Elias, P., ... Rubery, J. (1996). Feministfallacies: Areply to Hakim on women's employment. The British Journal of Sociology, 47, 167-174. 
Glavin, P., \& Schieman, S. (2012). Work-family role blurring and work-family conflict: The moderating influence of job resources and job demands. Work and Occupations, 39, 71-98.

Goh, Z., Ilies, R., \& Wilson, K. S. (2015). Supportive supervisors improve employees' daily lives: The role supervisors play in the impact of daily workload on life satisfaction via work-family conflict. Journal of Vocational Behavior, 89, 65-73.

Greenhaus, J. H., \& Beutell, N. J. (1985). Sources of conflict between work and family roles. The Academy of Management Review, 10, 76-88.

Hakim, C. (2000). Work-lifestyle choices in the 21st century: Preference theory. Oxford: Oxford University Press.

Hakim, C. (2002). Lifestyle preferences as determinants of women's differentiated labor market careers. Work and Occupations, 29, 428-459.

Hill, E. J. (2005). Work-family facilitation and conflict, working fathers and mothers, work-family stressors and support. Journal of Family Issues, 26, 793-819.

Hill, E. J., Märtinson, V. K., Ferris, M., \& Baker, R. Z. (2004). Beyond the mommy track: The influence of new-concept part-time work for professional women on work and family. Journal of Family and Economic Issues, 25, 121-136.

Hobson, B. (2011). The agency gap in work-life balance: Applying Sen's capabilities framework within European contexts. Social Politics: International Studies in Gender, State \& Society, 18, 147-167.

Hobson, B., \& Fahlén, S. (2009). Competing scenarios for European fathers: Applying Sen's capabilities and agency framework to work-family balance. The ANNALS of the American Academy of Political and Social Science, 624, 214-233.

IfD. (2010). Monitor Familienleben 2010: Einstellungen und Lebensverhältnisse von Familien: Ergebnisse einer Repräsentativbefragung: Berichtsband. Berlin: Institut für Demoskopie Allensbach.

Kelly, E. L., Ammons, S. K., Chermack, K., \& Moen, P. (2010). Gendered challenge, gendered response: Confronting the ideal worker norm in a white-collar organization. Gender \& Society, 24, 281-303.

Kossek, E.E., Pichler, S., Bodner, T., \&Hammer, L. B. (2011). Workplace social supportand work-family conflict: A meta-analysis clarifying the influence of general and work-family-specific supervisor and organizational support. Personnel Psychology, 64, 289-313.

Lewis, J., Campbell, M., \& Huerta, C. (2008). Patterns of paid and unpaid work in Western Europe: Gender, commodification, preferences and the implications for policy. Journal of European Social Policy, 18, 21-37.

van der Lippe, T. (2001). The effect of individual and institutional constraints on hours of paid work of women: An international comparison. In T. van der Lippe \& L. van Dijk (Eds.), Women's employment in a comparative perspective (pp. 221-243). New York, NY: Aldine de Gruyter.

Lucas, R. E., Clark, A. E., Georgellis, Y., \& Diener, E. (2003). Reexamining adaptation and the set point model of happiness: Reactions to changes in marital status. Journal of Personality and Social Psychology, 84, 527-539.

Maclnnes, J. (2005). Work-life balance and the demand for reduction in working hours: Evidence from the British Social Attitudes Survey 2002. British Journal of Industrial Relations, 43, 273-295.

Nangle, S. M., Kelley, M. L., Fals-Stewart, W., \& Levant, R. F. (2003). Workandfamily variables as related to paternal engagement, responsibility, and accessibility in dual-earner couples with young children. Fathering: A Journal of Theory, Research, and Practice about Men as Fathers, 1, 71-90.

Pfau-Effinger, B. (2009). The approach of the 'arrangement of work and welfare' to the cross-national analysis of formal and informal work. In B. Pfau-Effinger, L. Flaquer, \& P. H. Jensen (Eds.), Formal and informal work: The hidden work regime in Europe (pp. 21-35). New York, NY: Routledge.

Pollmann-Schult, M. (2008). Familiengründung und gewünschter Erwerbsumfang von Männern: Eine Längsschnittanalyse für die alten Bundesländer. Zeitschrift für Soziologie, 37, 498-515.

Pollmann-Schult, M. (2009). Arbeitszeitwunsch und - wirklichkeit im Familienkontext: Eine Analyse der Diskrepanzen zwischen präferierter und tatsächlicher Arbeitszeit. Soziale Welt, 60, 163-178.

Possinger, J. (2013). Vaterschaft im Spannungsfeld von Erwerbs- und Familienleben: 'Neuen Vätern' auf der Spur. Wiesbaden: Springer VS.

Reynolds, J., \& Aletraris, L. (2006). Pursuing preferences: The creation and resolution of work hour mismatches. American Sociological Review, 71, 618-638. 
Rosenfeld, R. A., \& Birkelund, G. E. (1995). Women's part-time work: A cross-national comparison.

European Sociological Review, 11, 111-134.

Schieman, S., Glavin, P., \& Milkie, M. A. (2009). When work interferes with life: Work-nonwork inter- ference and the influence of work-related demands and resources. American Sociological Review, 74, 966-988.

Sen, A. (1992). Inequality reexamined. Oxford: Oxford University Press. Sen, A. (1999).

Development as freedom. Oxford: Oxford University Press.

Shultz, T. R., \& Lepper, M. R. (1996). Cognitive dissonance reduction as constraint satisfaction. Psychological Review, 103, 219-240.

Stier, H., \& Lewin-Epstein, N. (2003). Time to work: A comparative analysis of preferences for working hours. Work and Occupations, 30, 302-326.

Thompson, C. A., Beauvais, L. L., \& Lyness, K. S. (1999). When work-family benefits are not enough: The influence of work-family culture on benefit utilization, organizational attachment, and work-family conflict. Journal of Vocational Behavior, 54, 392-415.

Thompson, C. A., \& Prottas, D. J. (2006). Relationships among organizational family support, job autonomy, perceived control, and employee well-being. Journal of occupational health psychology, 11(1), 100.

Thornthwaite, L. (2004). Working time and work-family balance: A review of employees' preferences.

Asia Pacific Journal of Human Resources, 42, 166-184. 